\title{
Natural diet of the spiny lobster, Panulirus echinatus Smith, 1869 (Crustacea: Decapoda: Palinuridae), from São Pedro and São Paulo Archipelago, Brazil
}

\author{
Góes, CA. ${ }^{\mathrm{a} *}$ and Lins-Oliveira, JE. ${ }^{\mathrm{b}}$ \\ ${ }^{\text {a} D i v i s a ̃ o ~ d e ~ S e n s o r i a m e n t o ~ R e m o t o, ~ I n s t i t u t o ~ N a c i o n a l ~ d e ~ P e s q u i s a s ~ E s p a c i a i s ~-~ I N P E, ~}$ \\ Av. dos Astronautas, n 1758, Jardim da Granja, CEP 12227-010, São José dos Campos, SP, Brazil

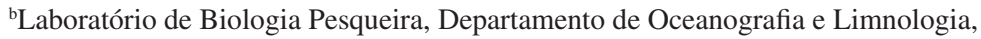 \\ Universidade Federal do Rio Grande do Norte - UFRN, \\ Av. Praia de Mãe Luíza s/n, Via Costeira, CEP 59014-100, Natal, RN, Brazil \\ *e-mail: camila.rudorff@gmail.com
}

Received March 26, 2007 - Accepted June 1, 2007 - Distributed February 28, 2009

(With 3 figures)

\begin{abstract}
The natural diet of the spiny lobster (Panulirus echinatus) from the São Pedro and São Paulo Archipelago was determined by stomach contents analysis of sixty-eight adult lobsters collected during October 2002, March, July and August 2003. Food items were grouped by gross taxa representing 11 food categories. Analysis included a qualitative (Frequency of Occurrence of item i - FOi) and a quantitative method (Volume of item i - Vi). A Feed Index (FI = FOi x Vi / 100) proposed by Lauzanne (1975) was also used to indicate the importance of each food category ( $>50$ : dominant, 25-50: essential, 10-25: unimportant, $<10$ : secondary). The most important food category determined by $\% \mathrm{FOi}$ and $\% \mathrm{Vi}$, was fish, followed by crustaceans, green algae, calcareous algae, and rocks. The remaining food categories contributed to less than $30 \%$ of FOi and 10\% of Vi. Although the Feed Index revealed no dominant food category in the diet of $P$. echinatus, fish was considered essential, crustaceans unimportant, and the remaining food categories were classified as secondary. According to the analysis, P. echinatus can be properly classified as an omnivorous and a generalist species, because it consumes a great diversity of organisms in several trophic levels. This species presents an opportunistic behaviour, feeding on the prey available at substratum. Future studies should address variations in natural diet related to sex, reproductive cycle, and seasonality.
\end{abstract}

Keywords: feeding habits, spiny lobster, Palinuridae.

\section{Dieta alimentar da lagosta espinhosa, Panulirus echinatus Smith, 1869 (Crustacea: Decapoda: Palinuridae), do Arquipélago São Pedro e São Paulo, Brasil}

\begin{abstract}
Resumo
A dieta alimentar da lagosta espinhosa, Panulirus echinatus, do Arquipélago São Pedro e São Paulo foi determinada a partir da análise de conteúdo estomacal de sessenta e oito espécimes adultos, coletados em outubro de 2002, março, julho e agosto de 2003. Os itens alimentares foram agrupados em grandes taxa, representando 11 categorias. As análises incluíram um procedimento qualitativo (Frequiência de Ocorrência do item i - FOi) e um método quantitativo (Volume do item i - Vi). Também foi utilizado o Índice Alimentar (IA= FOi x Vi / 100) proposto por Lauzanne (1975) para indicar a importância de cada categoria (>50: dominante, 25-50: essencial, 10-25: não-importante, <10: secundário). A categoria alimentar mais importante determinada pela FOi e Vi foi peixe, seguida de crustáceos, alga verde, alga calcária e rochas. As categorias alimentares restantes contribuíram com menos de 30\% da FOi e 10\% do Vi. Embora o Índice Alimentar não tenha revelado nenhum item dominante na dieta alimentar de $P$. echinatus, a categoria peixe foi considerada como essencial, crustáceos como não-importante e as categorias restantes foram classificadas como secundárias. De acordo com as análises, P. echinatus pode ser corretamente classificada como sendo uma espécie onívora e generalista, uma vez que se alimenta de uma grande diversidade de organismos em diferentes níveis tróficos. Esta espécie apresenta um comportamento oportunista, alimentando-se principalmente de presas disponíveis no substrato. Para estudos futuros, recomenda-se que sejam realizadas análises considerando variações da dieta alimentar associada ao sexo, ao ciclo reprodutivo e à sazonalidade.
\end{abstract}

Palavras-chave: hábitos alimentares, lagosta espinhosa, Palinuridae. 


\section{Introduction}

In Brazil, three species of spiny lobsters (Palinuridae) are harvested: Panulirus argus (Latreille), P. laevicauda (Latreille) and P. echinatus Smith. Two of these (P. argus and $P$. laevicauda) have fishery regulation, such as minimum size of capture and allowed periods of capture, only $P$. echinatus does not have legal management due to the lack of biological information. This species is distributed along the Atlantic Ocean and prefers offshore regions with rocky substrates, occurring particularly in oceanic islands, such as the São Pedro and São Paulo Archipelago, Fernando de Noronha, Rocas Atoll, Trindade, Cape Verde, Canary, Ascension and Saint Helena (Vianna, 1986; Pinheiro et al., 2003). Information about $P$. echinatus from the São Pedro and São Paulo Archipelago is restricted to few studies (e.g. Edwards and Lubbock, 1983; Pinheiro et al., 2003; Pinheiro and Lins-Oliveira, 2006). Edwards and Lubbock (1983) quote that this species is the most abundant decapod in the São Pedro and São Paulo Archipelago, and has great ecological importance in that region. Pinheiro et al. (2003) analyzed the population biology of P. echinatus in the archipelago and proposed that this population presents a sexual polymorphism linked to length and weight, by which males are bigger and heavier than females. Pinheiro and Lins-Oliveira (2006) studied the reproductive biology of this species.

Knowledge of an animal species natural diet is essential for studies on its nutritional requirements, its interactions with other organisms and its potential for culture (Williams, 1981). The objective of this study is to describe general feeding habitats of $P$. echinatus from the São Pedro and São Paulo Archipelago, attempting to better understand the biology of this important fishery resource.

\subsection{Study area characterization}

The São Pedro and São Paulo Archipelago (SPSP) constitutes a remote group of islets in the equatorial mid-Atlantic $\left(0^{\circ} 55^{\prime} \mathrm{N}\right.$ and $\left.29^{\circ} 21^{\prime} \mathrm{W}\right)$, about $1,100 \mathrm{~km}$ from the northeast coast of Brazil (Figure 1). Fauna and flora from the SPSP Archipelago are of notable interest because of its isolation, intermediate between South America and Africa, and its small size. Charles Darwin, who landed with HMS Beagle, conducted the first biological report of the SPSP in February 1832. However, most of the biological information was taken from the visit of HMS Challenger (Edwards and Lubbock, 1983). Later, the Cambridge Expedition arrived on the Archipelago and although it did not add greatly to the knowledge of the Archipelago's biology, it contributed by essentially delimiting habitat areas (Edwards and Lubbock, 1983). According to these authors, P. echinatus is the major benthic decapod present at the SPSP, revealing the eminent importance of this population for the trophic ecology in that place. In the SPSP P. echinatus are distributed to a depth of $25 \mathrm{~m}$ and they are present in caves and crevices.

For this study, lobsters were collected from a protected area called the bay (Figure 1). The depth in this area varies from 10 to $30 \mathrm{~m}$. This place is protected by Cabral, Northeast, Southeast and Belmonte Islands and is sheltered from the winds and external currents, even though there is a great flux of water draining the bay from east to west, which passes through the Southeast and Belmonte Islands.

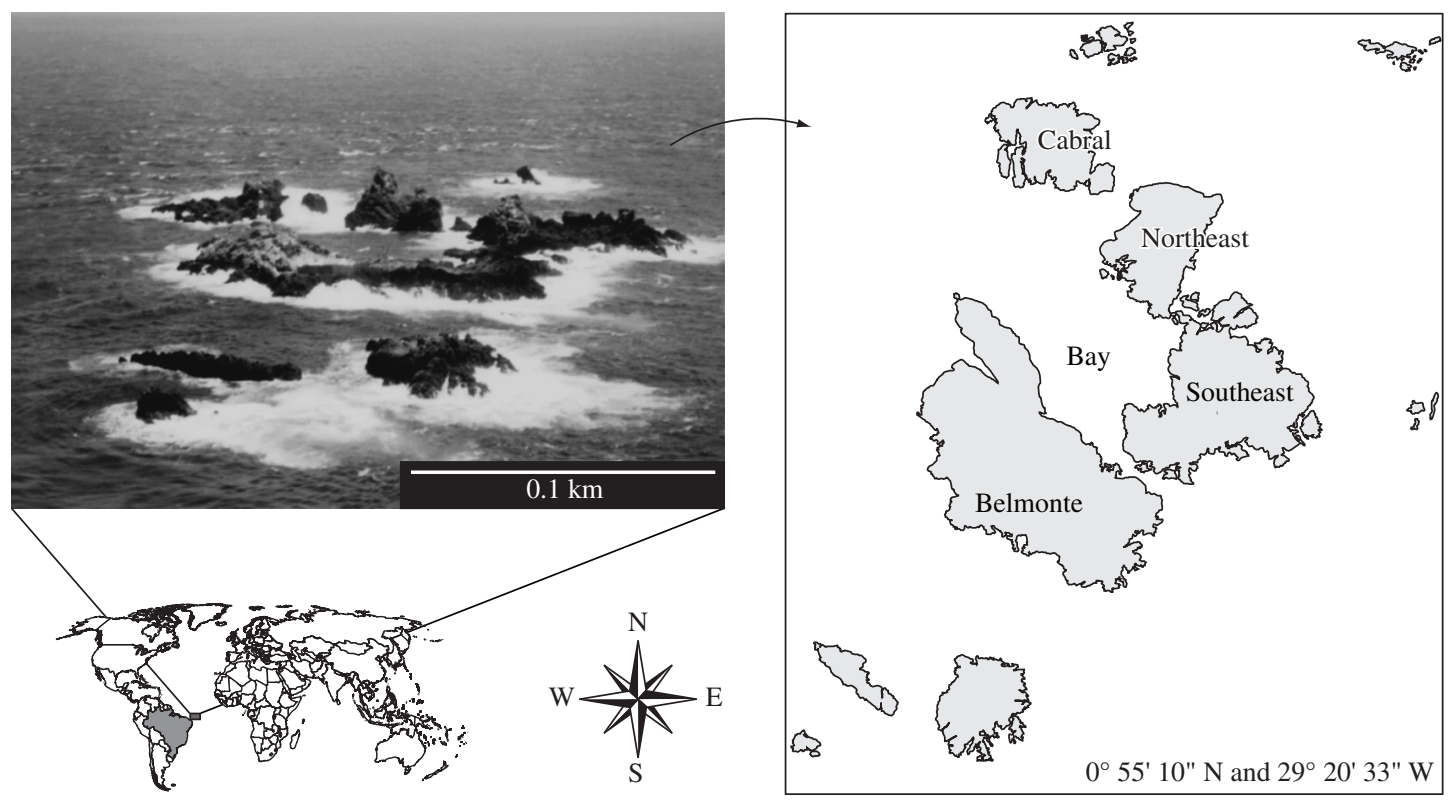

Figure 1. Study area. Aerial view of São Pedro and São Paulo Archipelago, Brazil. (Photo: Brazil Navy). 


\section{Material and Methods}

\subsection{Lobster sampling}

A food analysis of sixty-eight specimens of P. echinatus from the SPSP collected during October 2002 and March, July and August of 2003 was conducted.

Lobsters were collected by traps, cast out at dusk and retrieved in the early morning. At the upper part inside the trap, a small container with bait was attached. This container had some holes to enable the odor to escape but to prevent lobsters from accessing the contents.

The total length $(\mathrm{cm})$ was measured for all sampled lobsters and unexpected trawl selectivity was verified collecting mainly individuals over $12 \mathrm{~cm}$ in length (Figure 2) because of the mesh size $(5 \mathrm{~cm})$. According to Pinheiro and Lins-Oliveira (2006), this length characterizes an adult population. These authors calculated the medium length for the first maturation of $P$. echinatus between 13.5 and $14 \mathrm{~cm}$ of total length.

\subsection{Analysis}

Before the descriptive investigation, an analysis of the stomach repletion degree (GR) was conducted and a score was estimated: empty (I), partially full (II) and full (III). Only lobsters whose stomachs were considered partially full or full were analyzed (Joll and Phillips, 1984; Jernakoff et al., 1993) (Figure 3). This analysis is particularly true in decapods, because the stomach wall is not distensible as it is in fishes and places a relatively uniform limit on the maximum gut volume (Maller et al., 1983), providing a reasonably reliable means, even though the visual estimates of gut fullness is subjective (Hyslop, 1980; Williams, 1981; Cartes and Sarda, 1989; Jernakoff et al., 1993; de Lestang et al., 2000; Mantelatto and Christofoletti, 2001; Oh et al., 2001).
To conduct the descriptive analysis, 11 arbitrary food categories were created (Table 1). Items were recognized by optical stereomicroscope and identified to gross taxa because of their fragmentation and partial digestion. This identification was conducted with help from the Federal University of Rio Grande do Norte (northeast Brazil) specialists.

Gut contents were analyzed descriptive and qualitatively by frequency of occurrence (FOi) for each food category (Equation 1) (Aguilar and Malpica, 1993).

$$
\text { FOi }=\frac{\text { number of stomachs with item } \mathrm{i}}{\text { number of stomachs examined }} \times 100
$$

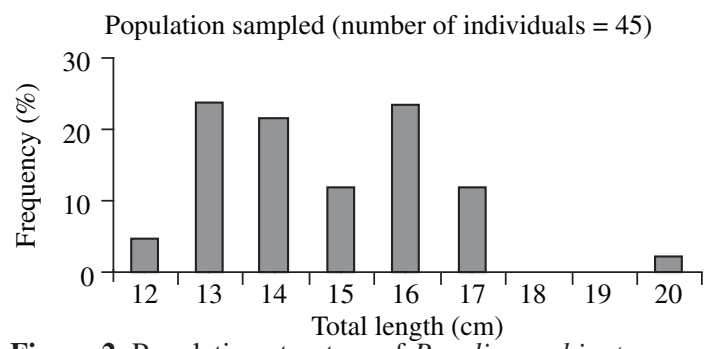

Figure 2. Population structure of Panulirus echinatus sampled from São Pedro and São Paulo Archipelago.

Stomach repletion degree (68 individuals)

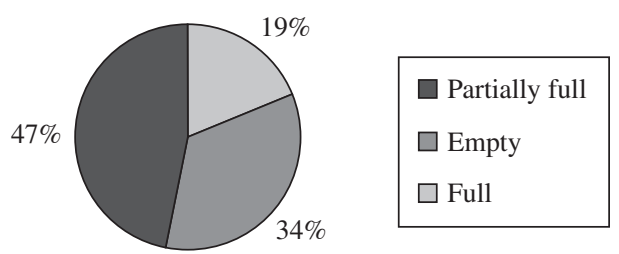

Figure 3. Stomach repletion degree of Panulirus echinatus sampled from São Pedro and São Paulo Archipelago.

Table 1. Description of food categories determined in this study.

\begin{tabular}{ll}
\hline \multicolumn{1}{c}{ Item } & \multicolumn{1}{c}{ Description } \\
\hline Fish (FI) & Category composed of tissue, bone and fish scales. \\
Digested Material (DM) & Floating soup of digested material. \\
Crustacean (CR) & $\begin{array}{l}\text { Category that consists mainly of carapace, antenna and chelas from crusta- } \\
\text { cean. }\end{array}$ \\
Algae, especially from Caulerpa genus. \\
Calcareous Algae (CA) & Calcareous algae. \\
Rocks (RO) & $\begin{array}{l}\text { Rock fragments. Besides the ingestion of this item must be accidental, we de- } \\
\text { cided to include it as a food item, since it could be associated with a series of } \\
\text { organisms (ex. bacterium, microalgae, fungus). }\end{array}$ \\
Synthetic Material (SM) & $\begin{array}{l}\text { Nylon cable. The ingestion of this item is accidental, but we chose to register it } \\
\text { due to its notable volume. }\end{array}$ \\
Non-Identified Material (NI) & $\begin{array}{l}\text { Non-Identified material. } \\
\text { Coralline algae. } \\
\text { Coralline Algae (CO) }\end{array}$ \\
Molusks (MO) & $\begin{array}{l}\text { Primarilly mollusk shells. } \\
\text { A wide variety of items presented in the stomachs, including hydrozoans, } \\
\text { bryozoans, fire worms and two different kinds of cnidarians: gorgonacea and }\end{array}$ \\
\end{tabular}


Despite the fact that FOi does not consider the volume of items, it does allow a visual notation of the relative importance of each food item and represents important data for ecological studies (Pillay, 1952).

The Volume (Vi) of each item within the stomach was determined by visual estimates using the volumetric method. This gives a quantitative idea of the stomach composition. To minimize the subjectivity associated with estimating the volume of food categories by sight, a millimetric Petri dish was used and the relative volume of each item to the total volume was estimated (FontelesFilho, 1989).

Hyslop (1980) recommends at least two different methods to analyze stomach contents. Hence, a Feed Index (FI) was determined (Lauzanne, 1975) (Equation 2).

$\mathrm{FI}=\frac{\mathrm{FOi} \times \mathrm{Vi}}{100}$

This index combines the food preference and biomass, and gives a score of importance of each item, establishing the selectivity of food $(<10$ secondary; 10-25 unimportant; 25-50 essential; $>50$ dominant).

\section{Results}

Results obtained in this study reveal fish (FI) as the principal food category, both in $\%$ FOi and \% Vi, followed by crustaceans (CR) representing $66.67 \%$ of the frequency of occurrence and $18.20 \%$ of the total volume. Green algae (GA) composed $51.11 \%$ of the frequency of occurrence and $13.73 \%$ of the total volume. Calcareous algae (CA) represented $48.89 \%$ of the frequency of occurrence and only $7.89 \%$ of the total volume. This item was followed by rocks (RO) that represented $42.22 \%$ of the frequency of occurrence and $2.24 \%$ of the total volume. The other items grouped contributed to less than $10 \%$ of the total volume (Table 2).

The analysis of the Feed Index did not verify dominant items, but FI was considered essential (27.15),
CR was unimportant (12.13) and the other items were judged as secondary to compose the diet of $P$. echinatus (Table 2).

\section{Discussion}

Spiny lobsters are considered key predators in various benthic habitats and their selective predation can have important effects on the structure of benthic communities (Phillips et al., 1980). The food finding behaviour and the selection of spiny lobsters is primarily based on chemoreception (Phillips et al., 1980). Adult spiny lobsters are nocturnal foragers and their diet includes mollusks, crustaceans, echinoderms and polychaeta (Kanciruk, 1980).

Decapods are classified as omnivorous presenting both carnivorous and saprophagous characteristics (Joll and Phillips, 1984; Stoner and Zimmerman, 1988; Mayfield et al., 2000; Cannicci et al., 2002; Sainte-Marie and Chabot, 2002). The variety of different classes of food items and the large number of organisms in the diet of $P$. echinatus indicates that it can be properly classified as a generalist feeder. Joll and Phillips (1984) defined P. cygnus (George) as typically opportunist, having a wide diet feeding primarily on small prey, they used a term "searcher" to classify this behaviour. This aspect is evident in results for this study, corroborating with the nonselectivity of prey by P. echinatus. Fernandes (1985) quoted echinoderm as the most important item composing the diet of Panulirus argus on the Continental Shelf of Brazil. In such an area, echinoderms are very abundant, which contrasts with the study area, where echinoderms are very scarce (Edwards and Lubbock, 1983; in situ observations). Edwards and Lubbock (1983) registered the presence of only two specimens of the urchin Eucidaris clavata (Mortensen) and many of the small ophiuroids Ophiactis savignyi (Müller and Troschel) in shallow waters. They also quoted that holothuroids Isostichopus badionotus (Selenka) and Holothuria (Halodeima) manningi (Pawson) were occasionally encountered. In this analysis, this item is completely

Table 2. Results of gut contents for Panulirus echinatus.

\begin{tabular}{lccc}
\hline \multicolumn{1}{c}{ Item } & Frequency of Occurrence (\%) & Volume (\%) & Feed index (Lauzanne, 1975) \\
\hline Fish (FI) & 84.44 & 32.15 & 27.15 \\
Digested Material (DM) & 84.44 & 16.18 & 13.66 \\
Crustacean (CR) & 66.67 & 18.20 & 12.13 \\
Green Algae (GA) & 51.11 & 13.73 & 7.02 \\
Calcareous Algae (CA) & 48.89 & 7.89 & 3.86 \\
Rock (RO) & 42.22 & 2.24 & 0.95 \\
Synthetic Material (SM) & 26.67 & 4.78 & 1.27 \\
Non-identified item (NI) & 26.67 & 2.38 & 0.63 \\
Coralline Algae (CO) & 20.00 & 0.98 & 0.20 \\
Mollusks (MO) & 20.00 & 0.89 & 0.18 \\
Other organisms (OO) & 17.78 & 0.58 & 0.10 \\
\hline
\end{tabular}


absent from $P$. echinatus stomachs, revealing the nonselectivity of prey.

The high frequency of occurrence and the great volume of digestive material are justified by the stomach anatomy. The stomach of the lobster is formed by strong muscles that cause a grinding action and a gastric mill, containing three large opposing teeth, one dorsal and two laterals, which triturates and sorts the food particles (Phillips et al., 1980). The consuming of the prey begins at the mouth, with its powerful jaws and continues in the stomach with the gastric mill (Pathwardan, 1935; Herrnkind et al., 1975).

The great presence of fish in the stomachs may not be related to true captures. Fish could have been wounded or dead, as mentioned by Kanciruk (1980).

The item crustacean was composed by carapace and lobster antenna. This fact was also quoted by Joll and Phillips (1984) when studying the diet of P. cygnus. These authors pointed out that exoskeleton material was derived from the ingestion of exuvia, rejecting the possibility of cannibalism of newly molted individuals.

Another important fact found in this study is the abundance of algae in the stomachs. In the study area, green algae Caulerpa racemosa (Forsskal) form a dense carpet (Edwards and Lubbock, 1983; in situ observations). This suggested that the spiny lobster probably eats the green algae to get small invertebrates that live within the algal mat, however Phillips et al. (1980) quote that the great quantity of the green algae reveals that this is not an accidental ingestion. This work shows a relevant presence of algae in the gut contents of $P$. echinatus from the SPSP, but this fact remains doubtful and a study on feeding behaviour is suggested to clarify this matter.

The calcareous algae was considered by the Feed Index as being secondary in the diet of $P$. echinatus, however, this item has a nutritional importance for these organisms, since Palinuridae (spiny lobster) has no calcareous plates (gastroliths) as found in Nephropidae (clawed lobsters). These plates are responsible for storing calcium during molt and allow the new exoskeleton to harden rapidly by mobilizing this store (Phillips et al., 1980). Joll and Phillips (1984) and Mayfield et al., (2000) quoted the presence of coralline algae composing the diet of Panulirus cygnus and Jasus lalandii (H. Milne Edwards), respectively. Kanciruk (1980) also relates that palinurids usually feed on calcareous organisms. This item corresponds to a great source of calcium carbonate to solidify the exoesqueleton.

The presence of rocks in the gut contents is probably an accidental ingestion while feeding on other organisms at the substratum, as spiny lobsters may present scraper habits.

In this way, it is verified that there were no dominant food items suggesting that $P$. echinatus can be considered omnivorous because vegetal and animal food were found in its stomach, generalist because it eats a great diversity of items and an opportunistic browser since it eats the prey available at the substratum. As a first study, the conclusions held here reveal important aspects of the trophic ecology of the P. echinatus in the SPSP. However, more studies are necessary to address variations in natural diet relating to sex, population structure, juvenile phase, reproductive cycle and seasonality.

Acknowledgements - The authors wish to thank the Brazilian Navy, SECIRM and the PROARQUIPÉLAGO program for the logistic help. Drs. Guilherme Fulgêncio and Maísa Clari Mendonça for their help with the descriptive analysis. Carlen Cooper, José Agripino Neto and Conrado Rudorff for their valuable comments on the manuscript and all the colleagues from the Fishery Biology Laboratory, University of Rio Grande do Norte (LABIPE/UFRN) that contributed to the collection of the lobster samples.

\section{References}

AGUILAR, AET. and MALPICA, ZGC., 1993. Biologia pesquera. Lima: Editorial Libertad. 432p.

CANNICCI, S., GOMEI, M., BODDI, B. and VANNINI, M., 2002. Feeding habitas and natural diet of the intertidal crab Pachygrapsus marmoratus: opportunistic browser or selective feeder?. Estuarine, Coastal And Shelf Science, vol. 54, no. 6, p. 983-1001.

CARTES, JE. and SARDA, F., 1989. Feeding ecology of the deepwater aristeid crustacean Aristeus antennatus. Marine Ecology Progress Series, vol. 54, no. 3, p. 229-238.

De LESTANG, S., PLATELL, ME. and POTTER, IC., 2000. Dietary composition of the blue swimmer crab Portunus pelagicus L.: Does it vary with body size and shell state and between estuaries?. Journal of Experimental Marine Biology and Ecology, vol. 246, no. 2, p. 241-257.

EDWARDS, A. and LUBBOCK, R., 1983. The ecology of Saint Paul's Rocks (Equatorial Atlantic). Journal of Zoology London, vol. 200, p. 51-69.

FERNANDES, LMB., 1985. Sobre a alimentação de lagosta Panulirus argus (Latreille, 1804): II - Estágios pós-puerulus e adulto. Recife: SUDENE, Divisão de Recursos Pesqueiros. Séries Estudos de Pesca 1.

FONTELES-FILHO, AA., 1989. Recursos pesqueiros: biologia e dinâmica populacional. Fortaleza: Imprensa Oficial do Ceará. 296p.

HERRNKIND, WF., VANDER WALKER, JA. and BARR, L., 1975. Population dynamics, ecology and behavior of spiny lobster Panulirus argus of St. John, US VI. IV: habitation, patterns of movement and general behavior. Science Bulletin of Natural History Museum of Los Angeles County, no. 20, p. 31-45.

HYSLOP, EJ., 1980. Stomach content analysis: a review of methods and their application. Journal of Fish Biology, vol. 17, no. 4 , p. 411-429.

JERNAKOFF, P., PHILLIPS, BF. and FITZPATRICK, JJ., 1993. The diet of Post-puerulus Western Rock Lobster, Panulirus cygnus George, at Seven Mile Beach, Western Australia. Australian Journal of Marine and Freshwater Research, vol. 44, p. 649-655. 
JOLL, LM. and PHILLIPS, BF., 1984. Natural diet and growth of juvenile western rock lobsters Panulirus cygnus George. Journal of Experimental Marine Biology and Ecology, vol. 75, no. 2, p. 145-169.

KANCIRUK, P., 1980. Ecology of juvenile and adult palinuridae (spiny lobsters). In COBB, JS. and PHILLIPS, BF. (Eds.). The biology and management of lobsters. New York: Academic Press, p. 59-96.

LAUZANNE, L., 1975. Régimes alimentaires d' Hydrocyon forskalii (Pisces, Characidae) dans le lac Tchad et ses tributaries. Cah. Orstom, Série Hydrobiologie, vol. 10, p. 105-121.

MALLER, RA., De BOER, ES., JOLL, LM., ANDERSON, DA. and HINDE, JP., 1983. Determination of the maximum foregut volume of western rock lobster (Panulirus cygnus) from field data. Biometrics, vol. 39, no. 3, p. 543-551.

MANTELATTO, FLM. and CHRISTOFOLETTI, RA., 2001. Natural feeding activity of the crab Callinectes ornatus (Portunidae) in Ubatuba Bay (São Paulo, Brazil): influence of season, sex, size, and molt stage. Marine Biology, vol. 138, no. 3 , p. $585-594$.

MAYFIELD, S., BRANCH, GM. and COCKCROFT, AC., 2000. Relationships among diet, growth rate and food availability for the South African rock lobster, Jasus lalandii (Decapoda, Palinuridae). Crustaceana, vol. 73, no. 7, p. 815-834.

OH, CW., HARTNOLL, RG. and NASH, RDM., 2001. Feeding ecology of the common shrimp Crangon crangon in Port Erin Bay, Isle of Man, Irish Sea. Marine Ecology Progress Series, vol. 214, p. 211-223.

PATHWARDAN, SS., 1935. On the structure and mechanisms of the gastric mill in Decapoda. IV - The structure of the gastric mill in reptantous Macrura. Proceedings of the Indian Academic Science, vol. 1, p. 414-422.
PHILLIPS, BF., COBB, JS. and GEORGE, RW., 1980. General biology. In COBB, JS. and PHILLIPS, BF. (Eds.). The biology and management of lobsters. New York: Academic Press, p. 1-82.

PILLAY, TVR., 1952. A critique of the methods of study of food of fishes. Journal of Zoology Society of India, vol. 4, no. 2, p. $185-200$.

PINHEIRO, AP. and LINS-OLIVEIRA, JE., 2006. Reproductive biology of Panulirus echinatus (Crustacea: Palinuridae) from São Pedro and São Paulo archipelago, Brazil. Nauplius, vol. 14, no. 2, p. 89-97.

PINHEIRO, AP., FREIRE, FAM. and LINS-OLIVEIRA, JE., 2003. Population biology of Panulirus echinatus Smith, 1869 (Decapoda: Palinuridae) from São Pedro e São Paulo archipelago, Northeastern Brazil. Nauplius, vol. 11, no. 1, p. $27-35$.

SAINTE-MARIE, B. and CHABOT, D., 2002. Ontogenic shifts in natural diet during benthic stages of American lobster (Homarus americanus), off the Magdalen Islands. Fishery Bulletin, vol. 100, no. 1, p. 106-116.

STONER, AW. and ZIMMERMAN, RJ., 1988. Food pathways associated with penaeid shrimps in a mangrove-fringed estuary. Fishery Bulletin, vol. 86, no. 3, p. 543-552.

VIANNA, ML., 1986. On the ecology and intraspecific variation in the spiny lobster Panulirus echinatus Smith, 1869, (Decapoda, Palinuridae) from Brazil. Crustaceana, vol. 51, no. 1, p. 25-37.

WILLIAMS, MJ., 1981. Methods for analysis of natural diet in portunid crabs (Crustacea: Decapoda: Portunidae). Journal of experimental marine biology and ecology, vol. 52, no. 1, p. 103-113. 